\title{
Relevance of a FLEGT-like approach for West and Central African cocoa sustainability
}

Elsa Sanial $^{\mathrm{a}}$, Guillaume Lescuyer ${ }^{\mathrm{b}}$, François Ruf ${ }^{c}$, Raphaël Tsanga ${ }^{\mathrm{d}}$

Tropical commodities such as timber, oil palm, coffee, soy or cocoa are commonly considered drivers of deforestation. Illegal agricultural land clearing is a debatable concept but it has been responsible for half of tropical deforestation since 2000 (Lawson 2014). Both the private sector and governments have started to acknowledge that some of these supply chains were not fully in compliance with national laws of the countries where products are grown (Lawson, 2015). The FLEGT approach has been designed by the European Union to deal with those two interrelated issues of legality and deforestation. Starting with timber, it encourages forest law enforcement, government and private sector transparency on forest activities, and participation of stakeholders for better governance. The EU also commits to stopping the import of illegal timber through a system of VPA (Voluntary Partnership Agreement) licenses and a due diligence approach. A reflection has started on the relevance of an extension of such a public-public agreement to other commodity chains such as cocoa and on the sustainability potential of legal cocoa in the context of increasing demand for sustainable and "zero-deforestation" cocoa and the private sector publicly making commitments to end deforestation (New York Declaration on Forests 2014). This question is studied in two different contexts: the "rebirth" of the cocoa sector in Cameroon and the post cocoa-boom challenges in Ivory Coast.

a University of Lyon III

b CIRAD, Senior Associate, CIFOR

CIRAD

CIFOR

\section{Cocoa is vastly illegal or a-legal - does this make it unsustainable?}

In both countries the sector is experiencing structural changes. For decades, Cameroon was an exception in the cocoa world, with very limited migration: until the 1970s, most cocoa was produced by very small farms (1-2 ha) created mainly by customary owners, under exceptional heavy shade, in the south of the country. This was in high contrast to larger smallholdings in Ivory Coast (6-7 ha), based on massive migration and zero-shade systems developed since the late 1960s (Leplai-deur and Ruf 1981). The migration process then gained in importance in Cameroon, the M'Bam and more significantly, the South-west regions (Losch et al., 1991). More recently, Cameroon has started to face the emergence of high-input capitalized elite agriculture, an adoption of full-sun systems, and political will for intensification and "modernization” (Pédélahore 2014).

In the meantime, the Ivorian cocoa sector consumed most of the forest in the country until the 2010s at the expense of "gazetted forests" and national parks. It was simultaneously challenged by the post-boom situation in many regions, with the depletion of forests, the ageing of fields, pests and disease attacks, and social conflicts (Ruf 1987; Ruf et al. 2018). In such contexts, the present legal framework can contribute to grant sustainability but its implementation faces serious obstacles in both countries: customary and formal land rights overlap, few smallholders own land titles, and labor contracts for workers are not frequent. In Ivory Coast, child labor and permanent forest encroachment 


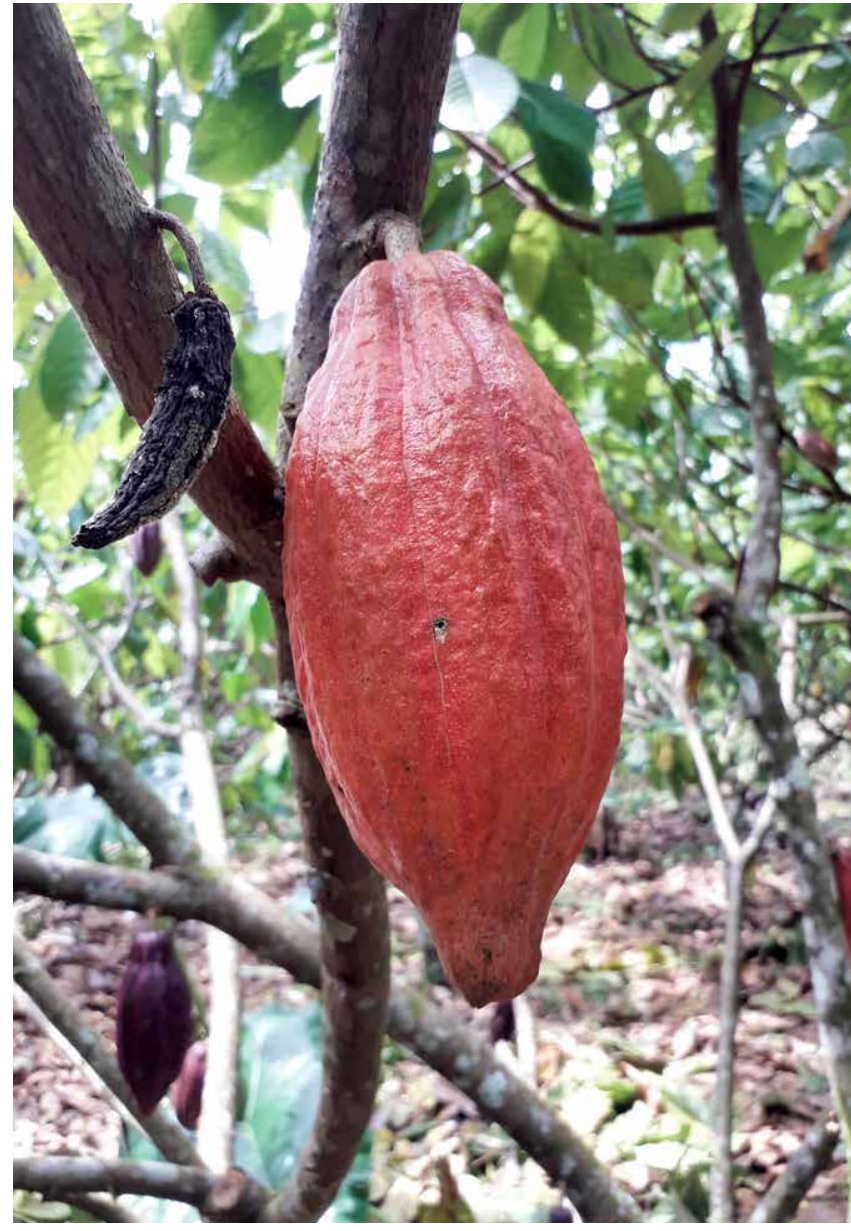

A ripe pod of cocoa, ready to be collected.

Photo by Guillaume Lescuyer.

are also significant legal issues. However, most legal constraints do not relate to cocoa production per se but to the general conditions for creating a cocoa plantation (with requirements for land and forest) or, mainly, to imposing conditions for marketing and export.

The regulatory framework provides little incentive to support sustainability at the cocoa production phase, for instance, when it comes to issues like deforestation, forest degradation, chemical use, working conditions and farmers living standards. To fill these gaps, ten years ago, private certification standards (especially UTZ and Rainforest Alliance) appeared to deal with these sustainability issues at the producer level.

\section{Is certified cocoa legal cocoa?}

Ivory Coast has experienced massive expansion of certification (UTZ certified 600000 tons of cocoa in 2016) in the last ten years and this approach is flourishing in Cameroon (UTZ certified 55000 tons of cocoa in 2018). Farming standards aim to answer rather generic sustainability issues (child labor, yields, democratic organizations) with few adjustments to national/local specificities.

Contrary to timber certification, legal compliance is not a concern put forward in cocoa certification even if it must take into account the national laws of the countries where crops are grown. When the law is stricter than the standard, the law is supposed to apply, when the standard is stricter and does not contradict the law, the standard may apply and rely on international texts. For instance, in the case of child labor, the minimum age of a worker set by Sustainable Agriculture Network standards is 15 years old whereas Cameroon law sets this age at 14 years old. To define authorized land conversion, certification standards firstly rely on national laws (protected areas, forest concessions, land rights) but add stricter principles set by High Conservation Value zoning.

Legislation compliance is a broad frame but not the target of cocoa certification. As many land and work laws are not enforced in rural areas there is a great share of "illegal" cocoa. Therefore, certified cocoa does not necessarily mean legally produced cocoa.

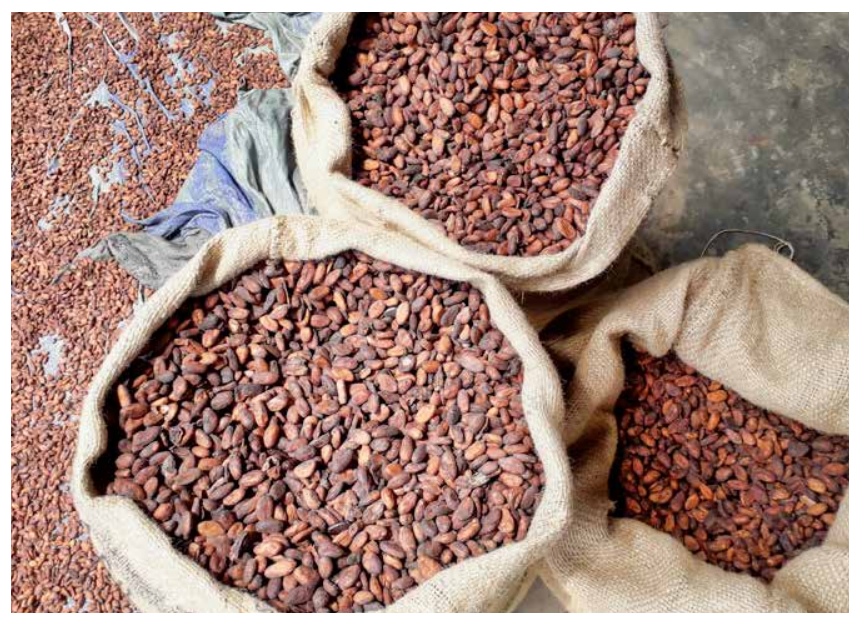

Bags of dry beans are checked at the exporter's warehouse.

Photo by Guillaume Lescuyer. 


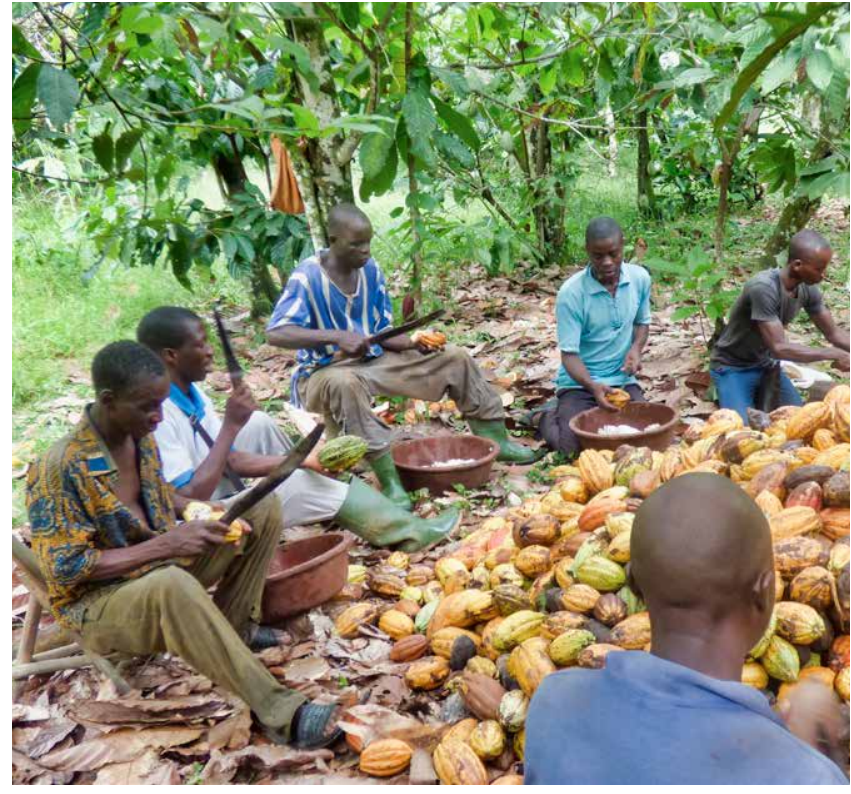

Men break cocoa pods.

Photo by Elsa Sanial.

In Cameroon, some producer representatives even insist on contractual aspects of certification that could be at the edge of the law. Once exporters have funded the certification of a cooperative and its members, the latter have to sell their cocoa to the exporter who funded them. Such moral contracts can ease the situation of some cooperatives to find buyers but they may give buyers an advantage in price negotiations.

As certified cocoa is similar to conventional cocoa, it cannot be specifically identified and tracked. It is often difficult for cooperatives to resist the temptation to mix both. This generates hidden and informal revenues mostly to cooperatives. Moreover, exporters are authorized to apply a "mass balance" principle, i.e. to mix certified and non-certified beans in the same processing unit and to sell certified chocolate in the same proportion. This practice is also allowed for timber in the FSC procedure - mainly for paper production but it raises some doubt about whether it really stands for what the consumers think they are buying (Ruf et al. 2013).

Taking into account these limits, is there a role for certification for more sustainable cocoa?

\section{Has certification prepared the ground for legal cocoa?}

Two main structural changes setting the basis for a FLEGT-like approach could be theoretically expected from certification: production traceability and platforms for better stakeholder participation in the value chain. Any comparison between timber and cocoa, from the perspective of extending a FLEGT approach, has to take into account an important difference between the two commodity chains: in the case of cocoa, at the first step of the chain there are thousands of farmers and their agronomic choices. Farm managements or cooperative organizations are too often "a black box" for outsiders and traceability is a challenge. Nevertheless, it is within this "black box" that decisions affecting sustainability are taken. Beyond a public traceability framework where every purchase of cocoa has to be reported, UTZ and RA have set their own traceability system. However, it only grants traceability from the first buyer (in other words: from the cooperative). For a legal approach such as FLEGT, traceability must start in the cocoa field at the producer level. Indeed, production legality cannot be guaranteed and environmental impacts estimated without taking into account what happens in cocoa fields.

It is too early to evaluate the structural changes brought about by certification in Cameroon, but in Ivory Coast some changes can be noted. Since its implementation in the country, certification has accelerated the constitution of cooperatives as only organizations of producers can be certified. Such organizations could be a basis for FLEGT implementation on cocoa: they could provide producers with administrative support to abide by the law (grouped land titling for instance) and they could represent producers in negotiations. However, most cooperatives have not been structured enough in Ivory Coast to provide such basis. Moreover, a majority of cooperatives are private family-run businesses rather than cooperatives and the likelihood of them defending producers' interests is debatable (Ruf et al. 2017).

In both countries, there is a lack of transparency in the management of premium (at the exporter and cooperative levels) (Bouessel 2017). Finally, for the last pillar of a VPA, there is no participation of smallholder organizations in the definition of certification standards and organization, and how the top-down organization of 


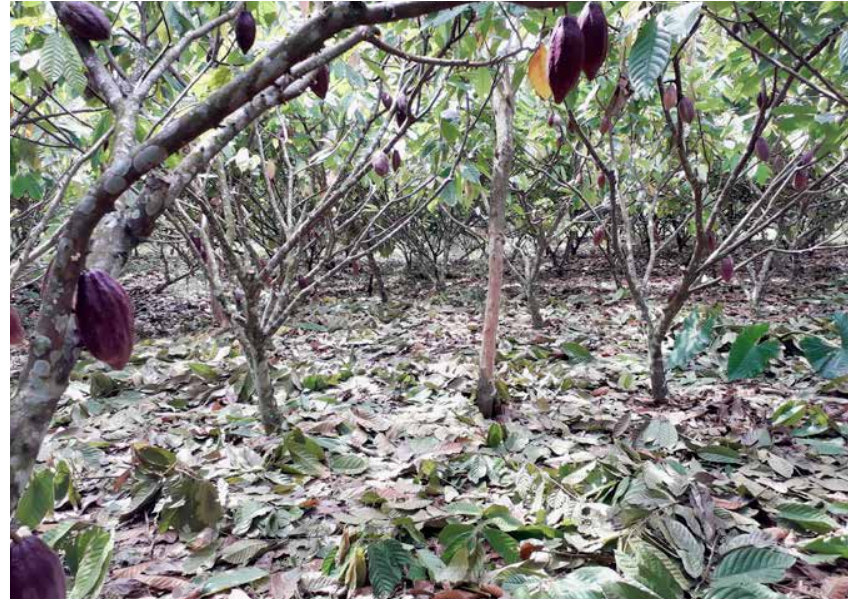

A clean and well-managed cocoa tree plantation. Photo by Elsa Sanial.

certification ignores local innovations and practices has been brought to light (Lemeilleur, N'dao and Ruf 2015; Sanial and Ruf 2018). To put it briefly, private certification has just started to support organizational changes but has still not transformed the cocoa sector to provide a strong basis for the traceability, transparency, participation and sustainability on which a VPA could easily rely.

\section{Would legal cocoa be sustainable?}

As cocoa production does not have proper legislation in either country, fully legal cocoa would not necessarily be fully sustainable cocoa. For example, agroforestry holds great sustainability stakes in both countries. In Cameroon, traditional agroforestry system preservation may be threatened by modernization (Jagoret et al. 2017). In Ivory Coast, agroforestry could be a way to increase tree cover in rural landscapes in a forest depletion context (Smith Dumont et al. 2014). In both countries, there are no legal mechanisms to avoid agroforestry conversion into simpler systems or full-sun ones. Therefore, using the law to reach sustainability would imply going beyond present legislation and adopting laws on cocoa production, though such laws would challenge producers' autonomy. In the present state of things, legal compliance is not sufficient or even necessary to reach sustainability.

\section{Conclusion}

"CLEGT" (Cocoa Law Enforcement Governance and Trade): Risks, opportunities and alternatives

As cocoa is a smallholder crop, the issue of illegal production has to be addressed from different viewpoints. For example, if one, from a legal perspective, considers that every cocoa farmer should have an individual land title and work contract for its employees then, yes, illegal production is an issue and most cocoa production is illegal. But from a legitimacy perspective, usufruct rights are acknowledged for farmers through customary access to land. In Cameroon, interlocutors never mention this land question as being an issue, and especially as an issue of legality.

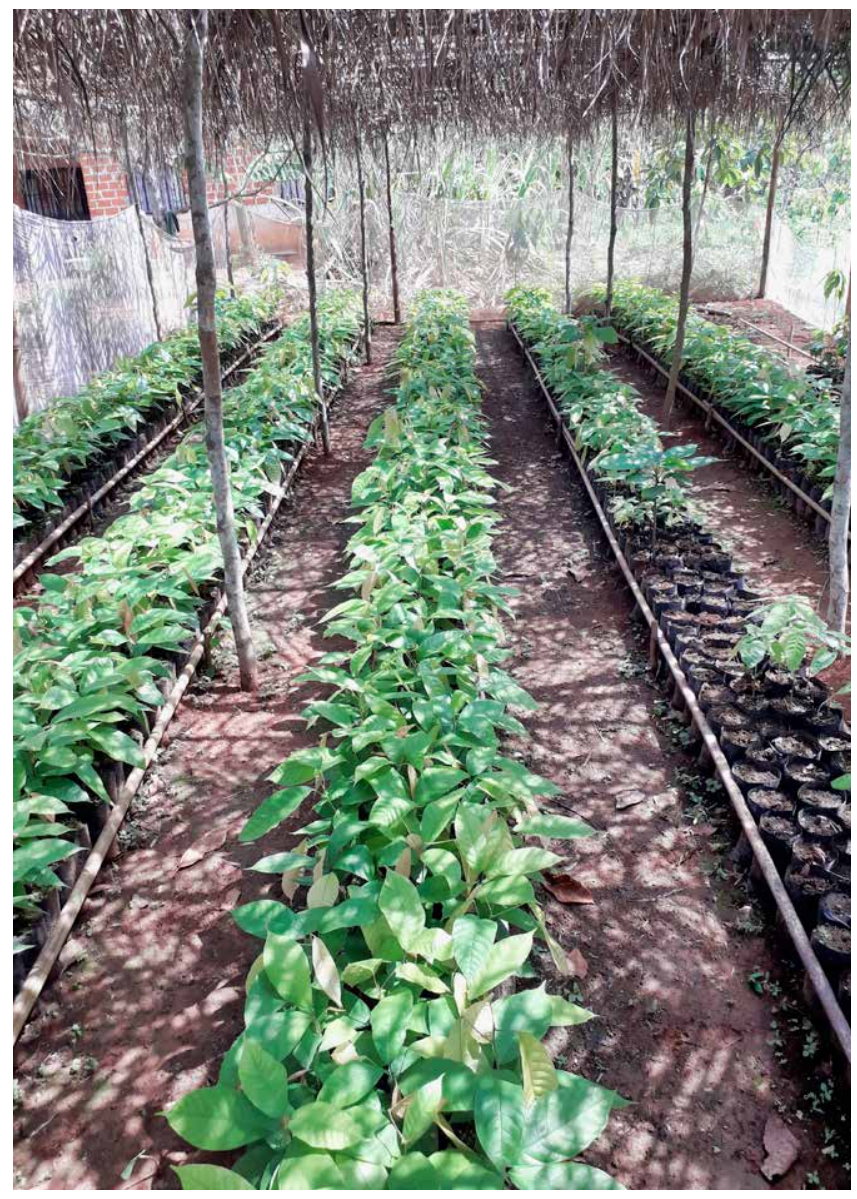

A village-made cocoa tree nursery.

Photo by Guillaume Lescuyer. 
Cameroon and Ivory Coast hold some potential for a VPA on cocoa: the recent interest of the state in the sector, clarity on a forest legal frame inherited from a VPA on timber, and the creation of smallholder organizations as potential dialogue platforms. A VPA would though, meet some challenges. The first and most important one would be traceability in a very complex value chain with hundreds of thousands of smallholders and many actors having interest in non-traceability or pseudo-traceability. In the case of Cameroon, a fully liberalized value chain adds to the difficulty. It would also hold risks, the main one being the marginalization of smallholders in a context of emerging elites. Indeed, full legal compliance would be difficult to reach and a VPA on agricultural commodities could lead to two-tier agriculture.

Finally, legality gaps exist in the sector but they do not necessarily lead to unsustainable practices. It is important to mention other issues. Agroforestry conversion is one of them and is not addressed by the law. To put it in a nutshell, a VPA would have to be re-thought to fit with agricultural commodities like cocoa as the stakes and commodity chain organization are very different from those of timber. The focus on legality is on the one hand not sufficient to reach sustainability and on the other hand socially dangerous in a context of smallholder agriculture.

FLEGT relies on the closure of the European market to "illegal" products. The EU can afford this with Cameroonian timber because it represents a very small share of timber demand for the EU. However, it would be more difficult for Ivorian cocoa, which represents the main share of European cocoa demand.

These weaknesses and risks do not mean that a VPA approach would not bear some opportunities for the cocoa sector and that public actors do not have any role to play in granting sustainability. In principle, if both countries have the agricultural, land and forestry administrations working together and with producer organizations, this could help set a coherent and clearer legal frame adapted to cocoa

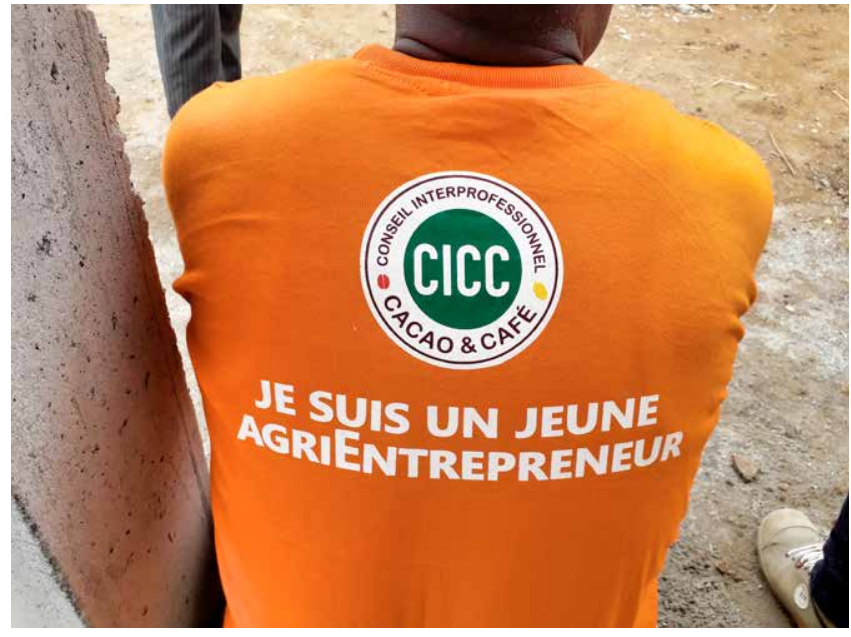

Several public and private initiatives support smallscale cocoa production.

Photo by Guillaume Lescuyer.

sustainability (such as status of outside forest trees, cocoa quality remuneration, and land titling inspired from customary arrangements).

Legality demands better control of the value chain by the state. The Ivorian administration is now considering legalization of gazetted forest encroachment through the creation of a "gazetted agroforests" status. Reforestation and cocoa production in these "agroforests" will be managed under the responsibility of a private actor. Legalizing these encroached gazetted forests may have two consequences that may be interpreted as challenging sustainability. Firstly, forest status is abandoned for these areas and, secondly, company workers may lose their independence. Finally, these companies may lose the smallholders' knowhow and accelerate the decline of cocoa quality and quantity.

If states and chocolate companies wish to participate in cocoa sustainability, the only way is to accept that they have something to learn from smallholders, technically and socially. 


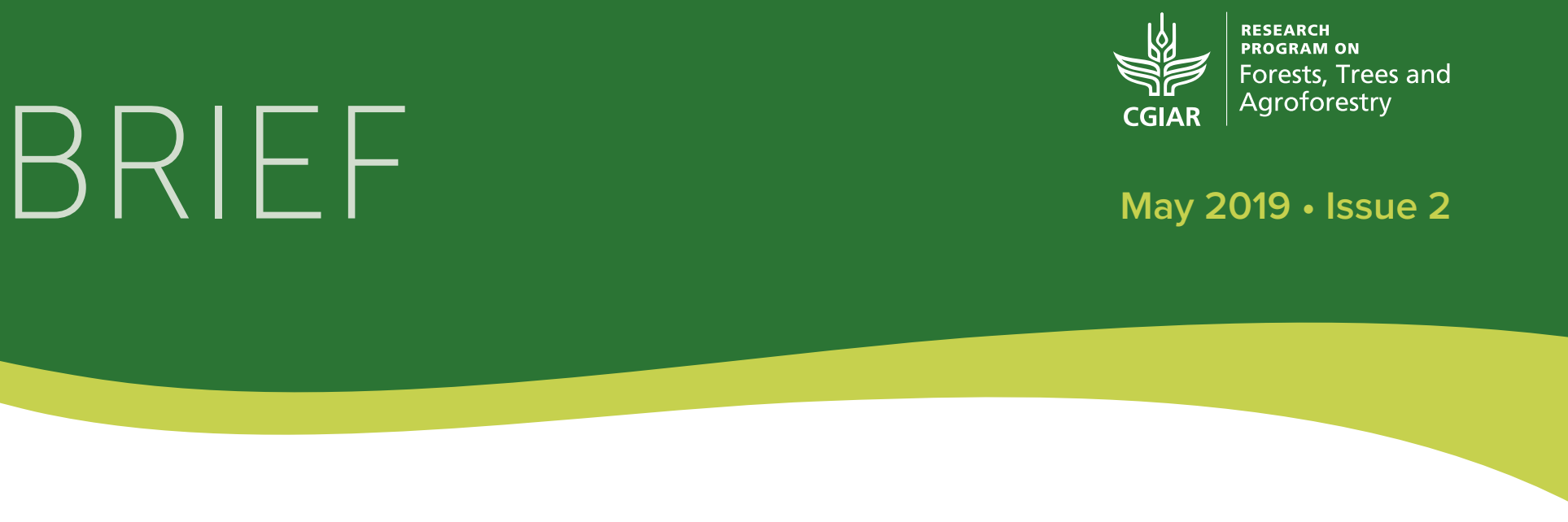

\section{References}

Bouessel, C. 2017. La fraude à la certification envahit la filière cacao. Jeune Afrique, 22 janvier, Edition Côte d’ivoire et Burkina SIFIJA édition.

Jagoret, P., Snoeck, D., Bouambi, E., Todem Ngnogue, H., Nyassé, S., Saj, S. 2017. Rehabilitation practices that shape cocoa agroforestry systems in Central Cameroon: Key management strategies for long-term exploitation. Agroforestry Systems, 15.

Lawson, S. 2014. Consumer Goods and Deforestation: An Analysis of the Extent and Nature of Illegality in Forest Conversion for Agriculture and Timber Plantations. Washington DC: Forest Trends Report Series.

Lemeilleur, S., N'dao, Y., Ruf, F. 2015. The productivist rationality behind a sustainable certification process: Evidence from the Rainforest Alliance in the Ivorian cocoa sector.

Leplaideur, A., Ruf, F. 1981. Quelques éléments sur l'évolution historique des économies paysannes de plantation en zone forestière africaine. Cahiers du CIRES, 30: 51-63.

Losch, B., Fusillier, J.L., Dupraz, P. 1991. Stratégies des producteurs en zone caféière et cacaoyère du Cameroun. Quelles adaptations à la crise? Documents systèmes agraires, n. 12. Montpellier.

Pédelahore, P. 2014. Systèmes agroforestiers à cacaoyers et transition capitaliste: l'exemple du Centre-Cameroun. Bois et Forêts des Tropiques (321): 55-66.

Ruf, F. 1987. Eléments pour une théorie sur l'agriculture des régions tropicales humides. De la forêt, rente différentielle au cacaoyer, capital travail. L'agronomie tropicale, 3(42).

Ruf, F., N'Dao, Y., Lemeilleur, S. 2013. Certification of cocoa. A high-risk strategy. Inter-réseaux. http://www. interreseaux. org/IMG/pdf/2013_ruf_et_al_gds_english.pdf.

Ruf, F., Varlet, F. 2017. The myth of zero deforestation cocoa in Côte d'Ivoire. ETFRN News, (58): 86-92.

Ruf, F., Uribe-leitz, E., Gboko, C., Galo, Kla A., Konan, A. 2018. L'innovation 'coopératives cacao' en Côte d'Ivoire. Entre mythes et dynamiques. Communication aux 12èmes journées de recherches en sciences sociales, Nantes, 13-14 décembre, 13 p.

Sanial, E., Ruf, F. 2018. Is kola the enemy of cocoa? Critical analysis of agroforestry recommendations made to Ivorian cocoa farmers. Human Ecology (first online), 12.

Smith Dumont, E., Gnahoua, G.M., Ohouo, L., Sinclair, F.L., Vaast, P. 2014. Farmers in Côte d'Ivoire value integrating tree diversity in cocoa for the provision of ecosystem services. Agroforestry System, 88(6): 1047-66. https://doi. org/10.1007/s10457-014-9679-4.

\begin{tabular}{l|l} 
RESEARCH \\
PROGRAM ON \\
Forests, Trees and \\
Agroforestry
\end{tabular}

FTA's work is supported by CGIAR Trust Fund: cgiar.org/funders

\section{The CGIAR Research Program on Forests, Trees and Agroforestry (FTA) is the world's largest research for development program to enhance the role of forests, trees and agroforestry in sustainable development and food security and to address climate change. CIFOR leads FTA in partnership with} Bioversity International, CATIE, CIRAD, ICRAF, INBAR and TBI.
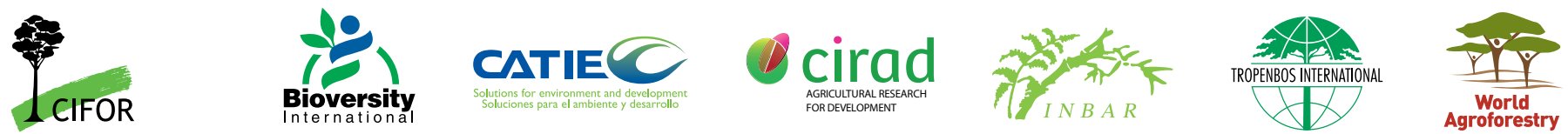